\title{
Tüketicilerin Ağızdan Ağıza Pazarlama Faaliyetlerinde Marka Sadakati ve Markaya Yönelik Algılanan Kalitenin Etkisi Üzerine Bir Araştırma
}

\author{
Zehra TÜRK \\ Muğla Sıtkı Koçman Üniversitesi, Marmaris Turizm MYO, \\ zehraturk@mu.edu.tr, ORCID:0000-0002-0769-1620
}

\begin{abstract}
Öz
Bu çalışmada, tüketicilerin marka sadakati ve markaya yönelik kalite algılarının ağızdan ağıza pazarlama faaliyetleri üzerindeki etkisi araştırılmaktadır. Bu amaçla, Muğla ili ve çevresinde DeFacto hazır giyim markasını kullanan tüketicilere yönelik alan araştırması gerçekleştirilmiştir. Alan araştırmasında veri toplama yöntemi olarak anket tekniği kullanılmıştır. Elde edilen veriler, betimsel istatistik analizi, korelâsyon analizi ve çoklu regresyon analizine tabi tutulmuştur. Araştırma neticesinde, marka sadakati ve algılanan kalitenin pozitif ağızdan ağıza pazarlama ile olumlu yönde, negatif ağızdan ağıza pazarlama ile ters yönlü ilişki içerisinde olduğu belirlenmiştir. Regresyon analizi sonuçlarına göre, marka sadakati ve algılanan kalitenin tüketicilerin pozitif ăgızdan ağıza pazarlama faaliyetlerinde olumlu etkisinin olduğu, negatif ağızdan ağıza pazarlama faaliyetlerini ise azalttı̆̆g sonucuna ulaşılmıştır. Sonuç olarak, tüketicilerin ağızdan ağıza pazarlama faaliyetlerinde marka sadakati ve kalite algılarının etkili olduğu tespit edilmiştir.
\end{abstract}

Anahtar Kelimeler: Ağızdan Ağıza Pazarlama, Marka Sadakati, Algılanan Kalite. Jel Sinıflandırma Kodları: M10, M30, M31.

\section{A Research on the Impact of Brand Loyalty and Perceived Quality in Brand on Word of} Mouth Marketing Activities of Consumers ${ }^{1}$

\begin{abstract}
In this study, the effect of consumers' brand loyalty and brand perceptions of quality on word-ofmouth marketing activities is investigated. For this purpose, in order to determine the effect of perceived quality and brand loyalty of consumers using DeFacto garment products in and around Muğla, a field research was conducted. In the field research, questionnaire technique was used as data collection method. The data obtained were subjected to descriptive statistics analysis, correlation analysis and multiple regression analysis.

As a result of the research, it has been determined that brand loyalty and perceived quality are positively associated with positive word of mouth marketing and negative word of mouth marketing. According to the results of the regression analysis, it was concluded that brand loyalty and perceived quality had a positive effect on consumers' positive mouth-to-mouth marketing activities and decreased negative mouth-to-mouth marketing activities. As a result, it has been determined that consumers' brand loyalty and quality perceptions are effective in the word of mouth marketing activities.
\end{abstract}

Keywords: Word of Mouth Marketing, Brand Loyalty, Perceived Quality. Jel Classification Codes: M10, M30, M31.

\footnotetext{
${ }^{1}$ Extended abstract is presented at the end of the article
}

Geliş Tarihi (Received): 04.11.2019 - Kabul Edilme Tarihi (Accepted): 27.04.2021

\section{Atıfta bulunmak için / Cite this paper:}

Türk, Z. (2021). Tüketicilerin ağızdan ağıza pazarlama faaliyetlerinde marka sadakati ve markaya yönelik algılanan kalitenin etkisi üzerine bir araştırma. Çankırı Karatekin Üniversitesi İ̈BF Dergisi, 11 (1), 1-27. Doi: 10.18074/ckuiibfd.642610. 


\section{Giriş}

Tüketiciler mal ve hizmet satın alımlarında etrafındaki kişilerin deneyimlerine önem vermektedirler. Satın almak istedikleri mal ve hizmet ile ilgili deneyimlerin paylaşıldığı internet ortamlarındaki yorumlar da tüketicilerin satın alma tercihleri üzerinde etkili olabilmektedir. Teknolojinin gelişmesi ile birlikte iletişim imkânları da gelişmiş ve tüketiciler kullandıkları mal ve hizmetler ile ilgili deneyimlerini daha çok kişi ile paylaşma imkânı bulmuşlardır. Tüketicilerin kullandıkları mallar ya da satın aldıkları hizmetler ile ilgili deneyimlerini diğer kişiler ile paylaşmaları ağızdan ağıza pazarlama olarak değerlendirilmektedir (Chae, Stephen, Bart ve Yao, 2016, s. 92). Ağıdan ağıza pazarlamanın tüketicilerin mal ve hizmetler ile ilgili beklentilerini şekillendirdiği ve tutumları üzerinde etkili olduğu görülmektedir (Anderson, 2003, s.115). Tüketicilerin çeşitli ürün kategorilerinde satın alma tercihlerini ve kararlarını etkilediği tespit edilmiştir (Berger ve Schwartz, 2011, s. 869). Turner ve Wrenn (1993, s. 19) tarafından yapılan araştırmada, tüketicilerin mal veya hizmetler ile ilgili memnuniyetlerini ortalama 3 kişiye anlattıkları, memnuniyetsiz olduğu durumları ise ortalama 11 kişiye anlattıkları tespit edilmiştir.

Ağızdan ağıza pazarlama faaliyetlerinin yaygınlaşması ile birlikte işletmeler, pazarlama departmanları bünyesinde oluşturdukları birimlerle internet ortamında kendi mal ve hizmetleri ile ilgili yayılan haberleri kontrol etmektedirler. Olumsuz yorumlarda bulunan ve memnuniyetsizliklerini paylaşan tüketiciler ile irtibat kurarak memnuniyetsizliklerin ortadan kaldırılması için çaba harcamaktadırlar. Mal ve hizmetlere yönelik olumlu paylaşımların çoğalması için de çeşitli yönlendirmelerde bulunarak, işletmeleri ile ilgili pozitif deneyimlerin yaygınlaşmasına olanak sağlamaktadırlar. Merlo, Eisingerich ve Auh (2014, s. 82) tarafından yapılan araştırmada yöneticilerin \%82'sinin sadık tüketicilerini ağızdan ağıza pazarlama konusunda yönlendirdikleri belirlenmiştir. Ağızdan ağıza pazarlamaya yönelik yapılan çalışmalarda, işletmelere tavsiye olarak marka sadakati yüksek olan tüketicilerin daha çok ağızdan ağıza pazarlama faaliyeti gerçekleştirmeleri için teşvik edilmesi önerilmektedir (Reicheld, 2003, s.46).

Tüketicilerine yönelik marka sadakati oluşturabilen işletmelerin rakiplerine göre daha avantajlı olacakları açıtır. Tüketicilerin mal ve hizmetlerden memnuniyet duymalarında etkili olan unsurlardan birisi de kalite algısıdır. Tüketicilerin mal ve hizmet markasına yönelik kalite algısının yüksek olması, o malı satın alma alışkanlığının sürdürülmesine katkı sağlayacaktır. Kalite algısı yüksek olan tüketicilerin ağızdan ağıza pazarlama konusunda daha istekli oldukları belirlenmiştir (Heskett, Jones, Loveman, Sasser ve Schlesinger, 1994, s. 164)

$\mathrm{Bu}$ çalışmada, tüketicilerin marka sadakati ve kalite algısı ile ağızdan ağıza pazarlama ilişkisi incelenmektedir. Ayrıca çalışmada literatürden farklı olarak, tüketicilerin pozitif ve negatif ağızdan ağıza pazarlama faaliyetlerinde marka sadakati ve kalite algısının birlikte etkisi araştırılmaktadır. Bu amaçla alan 
araştırması gerçekleştirilmiş ve elde edilen bulgular literatürde yer alan diğer araştırma sonuçları ile karşılaştırmalı olarak aktarılmaya çalışılmıştır.

\section{Kavramsal Çerçeve}

\subsection{Ağızdan Ağıza Pazarlama Kavramı}

Tüketicilerin mal ve hizmet satın alımından sonra elde ettikleri bilgi ve deneyimleri diğer tüketicilerle informal bir şekilde paylaşmaları ağızdan ağıza pazarlama olarak tanımlanmaktadır. Ağızdan ağıza pazarlamada kullanıcı deneyimleri paylaşıldığı için tüketiciler tarafından güvenilir bir kaynak olarak değerlendirilmektedir (Chung ve Darke, 2006, s. 270). Dick ve Basu (1994, s. 107) tarafından ağızdan ağıza pazarlama, tüketicilerin kendi istekleri ile satın aldıkları mallar ile ilgili başkaları ile iletişim kurmaları, memnuniyetlerini veya şikayetleri başkaları ile paylaşması şeklinde tanımlamaktadır. Richins (1983, s. 69)'e göre ağızdan ağıza pazarlama, tüketicilerin bir örgüt, mal veya mala dair kullanım deneyimlerini kendi aralarında gönüllü bir şekilde paylaşmalarıdır. $\mathrm{Bu}$ bilgi alışverişi örgütler için kendi avantajlarına kullanabilecekleri önemli bir bilgi kaynağıdır. Silverman (2007, s. 43) ise ağızdan ağıza pazarlamayı, tüketicilerin alışveriş sonrasında satın aldıkları mal ya da hizmetler ile ilgili görüşlerini firmadan bağımsız bir şekilde insanlara pozitif ya da negatif olarak aktarması şeklinde tanımlanmaktadır. Litvin, Goldsmith ve Pan (2008, s. 461) tarafindan yapılan tanımlamada ağızdan ağıza pazarlama, herhangi bir ticari kimliği bulunmayan kişilerin mal, hizmet veya işletme ile ilgili tecrübelerini yüz yüze görüşme şeklinde ifade etme süreci olarak değerlendirmektedir. Tüketicilerin alışveriş sonrasında mal ve hizmet ile ilgili olumlu görüş ve duygularını başkaları ile paylaşmasına pozitif ă̆ızdan ă̆ıza pazarlama denilmektedir. Tüketicilerin mal ve hizmet satın alımlarından kaynaklanan memnuniyetsizliklerini ve olumsuz görüşlerini başkalarına aktarması ise negatif ă̆ızdan ă̆ıza pazarlama olarak tanımlanmaktadır (Harrison-Walker, 2001, s. 61).

Ağızdan ağıza pazarlama, kişi ya da grupların hizmetler ve işletmeler hakkında ortaya koydukları iki yönlü iletişim türü olarak da değerlendirilmektedir. $\mathrm{Bu}$ iletişim türünde bilginin karşı tarafa aktarım maliyeti sıfıra inebilmektedir. İletişim teknolojilerinin gelişmesi ve internetin yaygınlaşması ile birlikte, ağızdan ağıza pazarlama faaliyetleri modern işletmeler için güçlü bir etkiye yol açmıştır. İnternet ile birlikte yoğunlaşan ağızdan ağıza pazarlama faaliyetleri, firmaların bu duruma hazırlıksız yakalanmalarına neden olmuştur (Güven, 2014, s. 52).

Ağızdan ağıza pazarlama faaliyetleri çerçevesinde mal ve hizmetlere yönelik bilgi yayılımı, organik ve geleneksel yayılma olmak üzere iki şekilde gerçekleşmektedir (Carl, 2006, s. 623). Organik bilgi yayılımı, marka ile ilgili online ya da yüz yüze çeşitli ortamlarda konuşan kişilerin ilgili kuruluşla herhangi bir bağının olmadığı, tamamen bağımsız bir şekilde görüşlerin paylaşıldığı bilgi yayılım türüdür. Organik yayılmada kişilerin kendi istekleri ile memnuniyetlerini 
ve memnuniyetsizliklerini başkaları ile paylaşma söz konusudur. Geleneksel bilgi yayılımı ise, önceden planlanmış ağızdan ağıza pazarlama kampanyası çerçevesinde gerçekleşmektedir. Geleneksel bilgi yayılımında, sosyal gruplar oluşturmak, bireylerin fikirlerini paylaşabilecekleri ortamlar geliştirmek, marka elçileri bulmak ve onları paylaşabilecekleri bilgiler konusunda desteklemek, çevrimiçi sohbet sitelerini takip etmek ve topluluklar içerisinde ağızdan ağıza pazarlama faaliyetlerini yaygınlaştırmak amacıyla gerçekleştirilen uygulamalar yer almaktadır (Carl, 2006, s. 624). Avon, Amway, Herbal Life, Oriflame, Tupperware gibi işletmelerin uyguladıkları ağızdan ağıza pazarlama faaliyetleri geleneksel bilgi yayılımının örnekleri arasında yer almaktadır. $\mathrm{Bu}$ markaları kullanan tüketiciler satış temsilcileri gibi hareket etmekte ve yakın çevrelerini mallar ile ilgili bilgilendirmektedirler (Güven, 2014, s. 54).

Ağızdan ağıza pazarlama uygulamalarında; viral pazarlama, elektronik ağızdan ağıza pazarlama ve fisıltı yoluyla (buzz) pazarlama olmak üzere üç yöntem bulunmaktadır (Bayındır, 2019, s. 38-41).

Viral pazarlama: Viral pazarlamada tüketiciler, mal ve hizmetler ile ilgili beğenilerinin e-mail veya sosyal medya aracılığıyla paylaşma eğilimindedirler (Dafonte-Gómez, 2013, s. 204). İnternet sitesi ve görsel materyaller aracılığıla tüketicilerde paylaşılmaya değecek şekilde mesaj oluşturma ve oluşturulan mesajların geniş kitlelere yayılmasını sağlamaya viral pazarlama denilmektedir (Sim ve Toprak, 2012, s. 4).

Elektronik ă̆ızdan ağıza pazarlama: Bilgi teknolojileri ve internetin gelişimi ile birlikte ağızdan ağız pazarlama anlayışı elektronik ortama taşınmıştır (Dellarocas, 2003, s. 1407; Thorson ve Rodgers, 2006, s. 40). Hennig-Thurau, Gwinner, Walsh ve Gremler (2004, s. 39)'e göre elektronik ağızdan ağıza pazarlama, mevcut tüketiciler ve müşteri olma potansiyelinde olan kullanıcıların internetteki insan grupları ile yaptıkları olumlu veya olumsuz yorumlardır. Elektronik ağızdan ağıza pazarlamada sosyal ağlar, forumlar ve internet üzerindeki bloglar kullanılmaktadır (Bayındır, 2019, s. 41).

Fisıltı yoluyla (Buzz) pazarlama: Bu pazarlama türünde mal ve hizmetleri tecrübe eden tüketicilerin diğer tüketiciler ile bir araya gelip deneyimlerini paylaştıkları konuşmaların yer aldığı ortamlar söz konusudur (Kahn ve Wind, 2005, s. 2). Fisıltı yolu ile ağızdan ağıza pazarlamada tüketiciler mesaj yaymakta zorlanmazlar ve iletilmek istenen mesajları doğal bir şekilde gerçekleştirdikleri için daha etkilidir (Thomas, 2004, s. 66). Bu pazarlama türünde tüketicilerin ve medya organlarının dikkatlerini çekmek ve markaya odaklanmalarını sağlamak amacıyla dikkat çekici, heyecan verici ve akılda kalıcı mesajlar ağızdan ağıza paylaşılmaya çalışılmaktadır (Mohr, 2007, s. 396). 


\subsection{Marka Sadakati Kavramı}

Marka sadakati kavramı tanımlanmadan önce sadık müşteri kavramının neyi ifade ettiğinin açıklanması gerekmektedir. Sadık müşteri, diğer işletmelerin malları için yaptıkları kampanyalardan etkilenmeden, işletmenin ürettiği mal ve hizmeti satın almak için kararlı olan ve yeni mal arayışında olmayan müşteri olarak tanımlanmaktadır (Çifci, 2006, s. 47). Elden (2009, s. 124)'e göre sadık bir müşteri kitlesi yaratabilmek için, fark edilir, rakip işletmelerde olmayan, yüksek düzeyde tatmin sağlayan marka deneyimine sahip mal ve hizmetler üretilmesi gerektiğini vurgulamaktadır. Marka sadakati, tüketicilerin satın aldıkları mal ve hizmetlere karşı bağlılıklarını ifade etmektedir (Pappu, Quester ve Cooksey, 2007, s.728). Tosun ve Turfanda (2018, s. 99) marka sadakatini, tüketicilerin kullanmakta olduğu mal ve hizmetlere yönelik fiyat ve mal özelliği bakımından değişiklik yapıldığında, diğer markalı mal ve hizmetlere geçme ihtimali olarak değerlendirmektedirler. Dick ve Basu (1994, s. 100)'ya göre marka sadakati, tüketicilerin bir markaya karş1 olumlu tutum sergilemeleri ve bu olumlu durumu devam ettirme gücü olarak tanımlanmaktadır. Uztuğ (2005, s. 34) güçlü bir markanın tanımını yaparken sadık müşteri yaratma gücüne değinmektedir.

Oliver (1999, s. 35) marka sadakatinin dört boyutunun olduğunu ifade etmektedir. Bilişsel sadakat boyutu, tüketicilerin marka ile ilgili edindikleri bilgiler çerçevesinde yaşadıkları deneyimlerin etkisinde kalarak marka tercihinde bulunmalarını ifade etmektedir. Duygusal sadakat boyutunda, tüketicilerin markaya ilişkin beğenilerinin yüksek olması ve memnuniyet düzeyine bağlı olarak satışın gerçekleşmesidir. Çabasal sadakat boyutunda ise, tüketicilerin ilgili markayı yeniden satın alma isteği ortaya çıkmaktadır. Eylemsel sadakat boyutunda, tüketicilerin satın almaya yönelik niyet ve istekleri eyleme dönüşmektedir.

\subsection{Markaya Yönelik Algılanan Kalite Kavramı}

Markaya yönelik algılanan kalite, tüketicilerin mal ve hizmetler ile ilgili markadan bekledikleri kaliteyi ifade etmektedir. Tüketicilerin markadan bekledikleri kalite ile malın gerçek kalitesi arasında farklılık olduğunda markaya yönelik algılanan kalite düzeyi düşmektedir. Kalite kavramı objektif ve subjektif olmak üzere iki şekilde değerlendirilmektedir. Objektif kalite algısı, ölçülebilir ve doğruluğu kanıtlanabilen kalite anlayışını ortaya koyarken, subjektif kalite anlayışı ise, tüketiciden tüketiciye algılama farklılıkları gösteren, sayısal olarak ölçümün mümkün olmadığı kalite algısını ortaya koymaktadır (Zeithaml, 1988, s. 41). Pappu, Quester ve Cooksey (2005, s. 145), markaya yönelik algılanan kalitenin mal ve hizmetleri diğer markalardan ayırt etmede etkili olduğunu, tüketicilerin kişisel değerlendirmelerine göre o markaya ait mal ve hizmetler için diğer markalara nazaran üstünlük ve mükemmellik hissini ortaya çıkardığını vurgulamıştır. Aaker (1991, s. 86), markaya yönelik kalite algısının tüketicilere göre farklılık gösterebileceğini, tüketicilerin marka ile ilgili yaşadıkları 
deneyimleri diğer markalar ile karşılaştırılarak, markaya yönelik kalite algılarının ortaya çıkacağını savunmuştur.

Markaya yönelik kalite algısı yüksek olan mal ve hizmetlerde, tüketicilerin beklentileri ile ilgili belirsizlikten kaynaklanan risk düzeyi düşük seviyede olmaktadır. Belirsizlik riskinin yüksek olduğu durumlarda tüketicilerin markaya yönelik kalite algıları düşük seviyede olmaktadır ve bu durum satın almaya yönelik karar verme sürecini olumsuz yönde etkilemektedir. Tüketiciler tarafından kalite algısı yüksek markalı mal ve hizmet üreten işletmelerin, rakiplerine nazaran daha başarılı olacakları aşikârdır (Yıldız ve Avc1, 2019, s. 194).

\subsection{Yazın Taraması ve Araştırmanın Hipotezleri}

Ağızdan ağıza pazarlamaya yönelik literatür araştırmaları incelendiğinde ulusal ve uluslararası bir çok çalışmanın olduğu görülmektedir. Trusov, Bucklin ve Pauwels (2009) tarafından yapılan araştırmada, ağızdan ağıza pazarlamanın gazete ve dergi yayınlarından yedi kat, kişisel satışa yönelik yapılan faaliyetlerden dört kat, radyo reklamlarından ise iki kat daha etkili olduğunu belirlemişlerdir. Ağızdan ağıza pazarlamanın etkisini ölçmek amacıyla Goyette, Ricard, Bergeron ve Marticotte (2010) tarafından yapılan araştırmada, ağızdan ağıza pazarlamanın gazetede çıkan haberlerden sekiz kat, doğrudan satışa yönelik yapılan aktivitelerden dört kat, radyoda yayınlanan reklamlardan iki kat daha fazla etkili olduğu sonucuna ulaşılmıştır. Silverman (2007) ve Alexandris, Tsaousi ve James (2007) yaptıkları çalışmalarda, ağızdan ağıza iletişimin etkisini araştırmış, tüketim deneyimleri sonucunda, mal veya hizmetin faydalarının ağızdan ağıza yayılmasının tüketicilerin satın alma tercihinde etkili olduğu sonucuna ulaşmışlardır. Godes ve Mayzlin (2004) ağızdan ağıza pazarlamayı büyüklük ve yayılma açısından incelemişlerdir. Araştırmalarında, internet üzerinden yapılan çevrimiçi sohbet gruplarındaki ağızdan ağıza pazarlamanın yayılım açısından daha etkili olduğunu tespit etmişlerdir. Hung (2008) yaptığı araştırmada, ağızdan ağıza pazarlamanın olumlu olduğunda tüketicilerin aynı markayı satın alma eğilimlerinin yüksek olduğunu belirtmiştir. Murray (1991) tarafından yapılan araştırmada, tüketicilerin satın aldıkları mal ve hizmete ilişkin karşılaşacakları riski en aza indirmek adına, ağızdan ağıza pazarlamadan yararlandıkları belirtilmiştir. Hizmet alımlarında mal alımına göre daha fazla risk algısı olduğu sonucuna ulaşılmıştır. Iacobucci ve Hopkins (1992) ağızdan ağıza pazarlamanın yayılım hızına yönelik yaptıkları araştırmada, kişisel olan malların yayılım hızının kişisel olmayan mallara göre daha yavaş olduğu sonucuna ulaşmışlardır. Hahn, Park, Krishnamurthi ve Zoltners (1994) tarafından yapılan araştırmada, ürün yaşam eğrisinde ağızdan ağıza pazarlamanın ilk aşamada daha etkili olduğu, ürün özelliklerinin yayılmasında ve pazar rekabeti açısından da ağızdan ağıza pazarlamanın etkili olduğu sonucuna ulaşmışlardır. Marangoz (2007) cep telefonu kullanıcılarına yönelik yaptığı araştırmada, ağızdan ağıza iletişimin tüketicilerin tekrarlı satın alma faaliyetlerinde etkili olduğunu belirtmiştir. 
Marka sadakatine yönelik literatürde birçok çalışma yer almaktadır. Kadaifçiler (2019) tarafından hazır giyim tüketicilerine yönelik yapılan araştırmada, marka sadakati ile tüketici satın alma karar süreci ilişkisi araştırılmış, marka sadakati oluşumunda malın kalite algısının, fiyatının ve duruşunun etkili olduğu tespit edilmiştir. Tan (2019) tarafından giyim ürünü tüketicilerine yönelik yapılan çalışmada, deneyimsel pazarlamanın marka sadakati üzerine etkisi araştırılmış, deneyimsel pazarlamanın marka sadakatini 0.39 oranında etkilediği tespit edilmiştir. Aynı çalışmada, marka sadakatinin tüketicilerin marka tercihlerini 0.38 oranında etkilediği belirlenmiştir. Khan ve Fatma (2019), Mosavi ve Kenarehfard (2013), Şahin ve Gültekin (2017), Gürbüz ve Doğan (2013), Yıldız ve Koç (2017) ve Hur, Kim ve Kim (2014) tarafindan marka güveninin marka sadakati üzerindeki etkisinin araştırıldığı çalışmalarda, pozitif yönlü ve anlamlı sonuçlar elde edilmiştir. Tüketici tatmininin marka sadakati üzerindeki etkilerini araştıran çalışmalarda da, tüketici tatmininin marka sadakatini pozitif yönde etkilediği belirlenmiştir (Yang, Yang, Chang ve Chien, 2017; Onaran, Bulut ve Özmen, 2013; Mostert, Petzer ve Weideman, 2016; Taşkın, Öztürk, Sürmeli ve Tuncay, 2016; Venkateswaran ve Ambrin, 2019; Dağcı Büyük ve Erciş, 2016). Marka aşk1 ile marka sadakati arasındaki ilişkiyi inceleyen araştırmalarda istatistik olarak anlamlı ve pozitif yönlü bir ilişki olduğu belirlenmiştir (Akın, 2017; Kalyoncuoğlu, 2017; Langner, Bruns, Fischer ve Rossiter, 2014; Drennan, Bianchi, Cacho-Elizondo, Louriero, Guibert, Proud, 2015; Bergkvist ve BechLarsen, 2010; Batra, Ahuvia ve Bagozzi, 2012; Huang, 2017; Carroll ve Ahuvia, 2006; Ünal ve Aydın, 2013). Aşkın ve İpek (2016) tarafından yapılan, marka aşkının marka sadakati üzerindeki etkisini inceleyen araştırmada, marka aşkının marka sadakatini 0.84 oranında pozitif yönlü etkilediği belirtilmiştir.

Markaya yönelik algılanan kalite ile ilgili literatürdeki çalışmalar incelenerek birkaç araştırma sonucu burada paylaşılmıştır. Pappu ve Quester (2015) tarafından yapılan, algılanan kalitenin marka yenilikçiliği ve marka sadakati arasındaki aracı rolünün incelendiği çalışmada, marka yenilikçiliğinin algılanan kalite ve müşteri memnuniyetini arttırdığı ve dolaylı olarak marka sadakatini de olumlu yönde etkilediği sonucuna ulaşılmıştır. Yıldız ve Koçan (2019) tarafindan, tüketici etnosentrizminin krem çikolata tüketicilerinin markaya yönelik algılanan kalite üzerindeki etkisinin araştırıldığı çalışmada, pozitif yönlü ve anlamlı etkisi olduğu tespit edilmiştir. Işık (2016) tarafindan algılanan kalitenin hastane marka değeri üzerindeki etkisine yönelik yapılan araştırmada, markaya yönelik kalite algısının hastane marka değeri üzerinde pozitif yönlü ve anlamlı etkisinin olduğu sonucuna ulaşılmıştır.

$\mathrm{Bu}$ çalışmada, tüketicilerin marka sadakati ve kalite algılarının ağızdan ağıza pazarlama faaliyetleri üzerindeki etkisi araştırılmaktadır. Severi, Ling ve Nasermoadeli (2014) tarafından yapılan benzer bir araştırmada marka sadakatinin ağızdan ağıza pazarlamayı 0.29 oranında, algılanan kalitenin ise 0.22 oranında etkilediği belirlenmiştir. Virvilaite, Tumasonyte, ve Sliburyte (2015) tarafından 
Gucci ve Dolce\&Gabbana markalarını kullanan tüketicilere yönelik yapılan araştırmada, marka sadakati ve algılanan kalitenin ağızdan ağıza pazarlama üzerinde pozitif ve anlamlı düzeyde etkisinin olduğu sonucuna ulaşılmıştır. Murtiasih ve Siringoringo (2013) tarafindan Endonezya'daki otomobil müşterilerine yönelik yapılan araştırmada marka sadakati ve algılanan kalitenin ağızdan ağıza pazarlama üzerinde pozitif yönde etkisi olduğu belirtilmektedir. Markovic, Iglesias, Singh ve Sierra (2018) tarafından yapılan araştırmada marka sadakati ve markaya yönelik algılanan kalite ile pozitif ağızdan ağıza pazarlama arasında pozitif yönlü ve anlamlı düzeyde ilişki olduğu sonucuna ulaşılmıştır. Yazgan, Çatı ve Kethüda (2014), tarafından yapılan çalışmada, algılanan kalitenin ağızdan ağıza pazarlama üzerinde 0.27 oranında, marka sadakatinin ise ağızdan ağıza pazarlama faaliyeti üzerinde 0.52 oranında etkisi olduğu tespit edilmiştir. Gülmez ve Özaltın Türker (2015) tarafından tur operatörü tüketicilerine yönelik yapılan araştırmada, pozitif ağızdan ağıza pazarlama ile markaya yönelik algılanan kalite arasında pozitif yönlü ve anlamlı düzeyde 0.48 oranında ilişki olduğu belirlenmiştir. Negatif ağızdan ağıza pazarlama ile markaya yönelik algılanan kalite arasında ise negatif yönlü ve anlamlı düzeyde 0.01 oranında düşük seviyede bir ilişki tespit edilmiştir. Yıldız (2015) tarafından mobil telefon kullanıcılarına yönelik yapılan, ağızdan ağıza pazarlamanın marka sadakati ve markaya yönelik algılanan kalite üzerindeki etkisini inceleyen araştırmada istatistiksel olarak anlamlı sonuçlar elde edilmiştir. Ağızdan ağıza pazarlamanın markaya yönelik algılanan kaliteyi 0.88 oranında, marka sadakatini ise 0.74 oranında etkilediği tespit edilmiştir.

Literatürde yer alan marka sadakati, markaya yönelik algılanan kalite ve ağızdan ağıza pazarlama faaliyetlerine yönelik çalışmalar incelendikten sonra, araştırmanın amacına uygun olarak aşağıdaki hipotezler geliştirilmiştir.

Hipotez 1: Tüketicilerin marka sadakati ile pozitif ă̆ızdan ă̆ıza pazarlama faaliyetleri arasında pozitif yönlü bir ilişki vardır.

Hipotez 2: Tüketicilerin marka sadakati ile negatif ă̆ızdan ăgıza pazarlama faaliyetleri arasında negatif yönlü bir ilişki vardır.

Hipotez 3: Tüketicilerin markaya yönelik kalite algıları ile pozitif ă̆ızdan ă̆ıza pazarlama faaliyetleri arasında pozitif yönlü bir ilişki vardır.

Hipotez 4: Tüketicilerin markaya yönelik kalite algıları ile negatif ă̆ızdan ağıza pazarlama faaliyetleri arasında negatif yönlü bir ilişki vardır.

Hipotez 5: Tüketicilerin marka sadakati ve markaya yönelik kalite algıları, pozitif ă̆ızdan ă̆ıza pazarlama faaliyetlerini pozitif yönde etkilemektedir.

Hipotez 6: Tüketicilerin marka sadakati ve markaya yönelik kalite algıları, negatif ă̆ızdan ağıza pazarlama faaliyetlerini negatif yönde etkilemektedir. 


\section{Metodoloji}

\subsection{Araştırmanın Amacı ve Yöntemi}

$\mathrm{Bu}$ çalışmanın amacı, tüketicilerin pozitif ve negatif ağızdan ağıza pazarlama faaliyetlerinde, markaya duyulan sadakat ve markaya yönelik kalite algısının etkilerini ölçmektir. Ayrıca pozitif ve negatif ağızdan ağıza pazarlama faaliyetleri ile marka sadakati ve markaya yönelik kalite algısı arasındaki ilişkiye de yer verilmiştir. Araştırmanın amacına ulaşmak için, Muğla ili ve çevresinde DeFacto hazır giyim markasını kullanan tüketicilere yönelik anket uygulaması gerçekleştirilmiştir. Anket uygulaması neticesinde elde edilen veriler, betimsel istatistik analizi, korelâsyon analizi ve regresyon analizi ile çözümlenmeye çalışılmıştır.

\subsection{Araştırmanın Örneklemi ve Veri Toplama Aracı}

Araştırma Muğla ili ve çevresinde DeFacto hazır giyim markasını kullanan tüketicileri kapsamaktadır. Muğla ili ve çevresinde, DeFacto hazır giyim markası mallarını daha önce satın almış ve kullanmış tüketicilere anket uygulaması gerçekleştirilmiştir. Tüketicilerine kolay ulaşılabilmesi ve geniş tüketici kitlesine sahip olmasından dolayı DeFacto markası örneklem olarak seçilmiştir. Araştırma

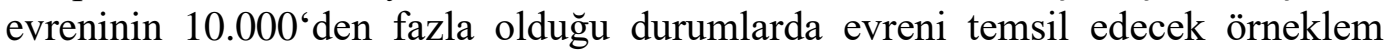
sayısının en az 384 olması gerekmektedir (Sekaran, 1992, s. 253). Araştırmaya 525 DeFacto hazır giyim markalı malları kullanan tüketici katılmıştır. Araştırmada kullanılan ölçeklere ilişkin bilgiler kısaca şu şekildedir:

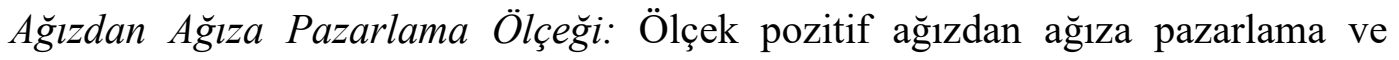
negatif ağızdan ağıza pazarlama olmak üzere iki boyuttan oluşmaktadır. Her iki boyutta da beş ifade olmak üzere, ağızdan ağıza pazarlama ölçeğinde toplam on ifade yer almaktadır. Ölçeğin orijinali Godes ve Mayzlin (2004) tarafından oluşturulmuştur. Ölçek, Yıldız (2014) tarafından Türkçe' ye uyarlanarak geçerlilik ve güvenilirlik analizleri gerçekleştirilmiştir. Pozitif ağızdan ağıza pazarlama ölçeğinin 0.90 , negatif ağızdan ağıza pazarlama ölçeğinin ise 0.82 oranında güvenilir olduğu tespit edilmiştir (Yıldız, 2014, s.116). Araştırmacı tarafindan ağızdan ağıza pazarlama ölçeği DeFacto kullanıcılarına göre düzenlenerek anket formu oluşturulmuştur.

Marka Sadakati Ölçeği: Tüketicilerin marka sadakatine yönelik ifadelere katılım düzeyini belirlemek üzere altı ifadeden oluşan marka sadakati ölçeği kullanılmıştır. Ölçek tek boyut olarak analizlerde kullanılmıştır. Ölçeğin orijinali Yoo ve Donthu (2001) tarafından oluşturulmuş, araştırmacı tarafından DeFacto hazır giyim markasına göre uyarlanmıştır.

Marka Yönelik Algılanan Kalite Ölçeği: Bu ölçekte tüketicilerin markaya yönelik kalite algılarını belirlemek amacıyla altı ifade kullanılmıştır. Ölçeğin orijinalinde 
de olduğu gibi tek boyut olarak değerlendirmeye tabi tutulmuştur. Ölçeğin orijinali Netemeyer vd. (2004) tarafından oluşturulmuş, araştırmacı tarafından DeFacto markasına göre uyarlanmıştır. Analizlerde algılanan kalite ölçeği tek boyut olarak kullanılmıştır.

Araştırmada kullanılan ölçeklerde yer alan ifadeler 5'li likert skalasına göre cevaplanmıştır. Ölçekte yer alan puanlar, 1-Kesinlikle katılmıyorum, 5-Kesinlikle katılıyorum aralığında değerlendirilmiştir.

\subsection{Araştırma Bulgularının Değerlendirilmesi}

Araştırmada tüketicilerden elde edilen anketlerin çözümlenmesinde, IBM SPSS 22.0 istatistik paket programından yararlanılmış ve hipotezlerin değerlendirilmesinde \% 95 güven aralığı dikkate alınmıştır.

\subsubsection{Demografik Veriler}

Araştırmaya DeFacto hazır giyim markasını kullanan 525 tüketici katılmıştır. Tüketicilerin yaş dağılımları incelendiğinde; 69 (\%13.1)'u 20 yaş altında, 213 (\%40.6)'ü 20 ile 29 yaş aralığında, 126 (\%24.0)'sı 30 ile 39 yaş aralığında, 102 (\%19.4)'si 40 ile 49 yaş aralığında ve 15 (\%2.9)'i 50 yaş ve üzerindeki kişilerden oluşmaktadır. Katılımcıların cinsiyete göre dağılımlarına bakıldığında ise; 321 (\%61.1)'i kadın, 204 (\%38.9)'ü erkek tüketicilerden oluşmaktadır. Araştırmaya katılan tüketicilerin medeni durumlarına göre dağılımında ise; 282 (\%53.7) kişinin evli, 243 (\%46.3) kişinin bekâr olduğu tespit edilmiştir.

\subsubsection{Güvenilirlik Analizi ve Tanımlayıcı İstatistikler}

Araştırmada kullanılan anket formunda yer alan ölçeklere ilişkin güvenilirlik analizi gerçekleştirilmiş, ölçeklerin tamamı yüksek düzeyde güvenilir bulunmuştur. Pozitif ağızdan ağıza ölçeği güvenilirlik analizi (Cronbach's Alpha) değeri 0.778 , negatif ağızdan ağıza pazarlama ölçeği güvenilirlik analizi değeri 0.883 'tür. Marka sadakati ölçeği güvenilirlik analizi değeri 0.823 , markaya yönelik algılanan kalite ölçeği güvenilirlik analizi değeri ise 0.866 'dır. Kalaycı (2008)'ya göre güvenilirlik analizi değeri 0.60 ile 0.80 arasında ise ölçek oldukça güvenilir, 0.80 ile 1.00 arasında ise yüksek derecede güvenilir olarak değerlendirilmektedir. Güvenilirlik analizi sonuçlarına göre; pozitif ağızdan ağıza pazarlama ölçeği oldukça güvenilir, negatif ağızdan ağıza pazarlama, marka sadakati ve markaya yönelik algılanan kalite ölçeği ise oldukça yüksek düzeyde güvenilir bulunmuştur.

Araştırmaya katılan tüketicilere uygulanan anket formunda yer alan ölçeklere ilişkin betimsel istatistik analizi sonuçları aşağıda gösterilmektedir. 
Tablo 1: Pozitif Ağızdan Ă̆ıza Pazarlama Ölçeği Betimsel İstatistiği

\begin{tabular}{|l|c|c|c|}
\hline $\begin{array}{l}\text { Pozitif Ă̆ızdan Ağıza Pazarlama } \\
\text { Ölçeği }\end{array}$ & Kişi & Ortalama & $\begin{array}{c}\text { Standart } \\
\text { Sapma }\end{array}$ \\
\hline DeFacto markasını tavsiye ederim. & 525 & 2.97 & 1.26 \\
\hline $\begin{array}{l}\text { DeFacto markasının iyi yönlerini } \\
\text { anlatırım. }\end{array}$ & 525 & 3.17 & 1.32 \\
\hline $\begin{array}{l}\text { DeFacto markası hakkında çoğunlukla } \\
\text { pozitif şeyler söylerim. }\end{array}$ & 525 & 3.12 & 1.40 \\
\hline $\begin{array}{l}\text { DeFacto markasından favorim olarak } \\
\text { bahsederim. }\end{array}$ & 525 & 2.97 & 1.28 \\
\hline $\begin{array}{l}\text { DeFacto markasını satın almaları için } \\
\text { insanları teşvik ederim. }\end{array}$ & 525 & 2.94 & 1.24 \\
\hline $\begin{array}{l}\text { Pozitif Ağızdan Ağıza pazarlama } \\
\text { (Genel Ortalama) }\end{array}$ & $\mathbf{5 2 5}$ & $\mathbf{3 . 0 3}$ & $\mathbf{1 . 0 3}$ \\
\hline
\end{tabular}

Araştırmaya katılan DeFacto hazır giyim markası kullanıcılarının bu markaya ilişkin ifadelerinin yer aldığı pozitif ağızdan ağıza pazarlama ölçeğinin genel ortalaması 3.03'tür. Anket uygulamasının cevapları 5'li likert ölçeğine göre değerlendirildiğinden, araştırmaya katılan DeFacto hazır giyim markası kullanıcılarının pozitif ağızdan ağıza pazarlamaya yönelik ifadelerinin orta düzeyde olduğunu söylemek mümkündür.

Tablo 2: Negatif Ağızdan Ağıza Pazarlama Ölçeği Betimsel İstatistiği

\begin{tabular}{|l|c|c|c|}
\hline $\begin{array}{l}\text { Negatif Ağızdan Ağıza Pazarlama } \\
\text { Ölçeği }\end{array}$ & Kişi & Ortalama & $\begin{array}{c}\text { Standart } \\
\text { Sapma }\end{array}$ \\
\hline $\begin{array}{l}\text { DeFacto markasının memnun } \\
\text { kalmadığım yönleri hakkında sıklıkla } \\
\text { konuşurum. }\end{array}$ & 525 & 3.07 & 1.19 \\
\hline $\begin{array}{l}\text { DeFacto markası ile ilgili olarak olumsuz } \\
\text { yorumlar yaparım. }\end{array}$ & 525 & 3.16 & 1.10 \\
\hline $\begin{array}{l}\text { DeFacto markası ile ilgili yaşadığım } \\
\text { olumsuzlukların anlatılmasını doğru } \\
\text { bulurum. }\end{array}$ & 525 & 2.86 & 1.23 \\
\hline $\begin{array}{l}\text { DeFacto markası hakkında çoğunlukla } \\
\text { olumsuz şeyler söylerim. }\end{array}$ & 525 & 2.66 & 1.18 \\
\hline DeFacto markasını övmem. & 525 & 2.94 & 1.33 \\
\hline $\begin{array}{l}\text { Negatif Ăğıdan Ăğıa pazarlama } \\
\text { (Genel Ortalama) }\end{array}$ & $\mathbf{5 2 5}$ & $\mathbf{2 . 9 4}$ & $\mathbf{0 . 8 8}$ \\
\hline
\end{tabular}

Katılımcıların DeFacto hazır giyim markasına ilişkin ifadelerinin yer aldığ negatif ağızdan ağıza pazarlama ölçeğinin genel ortalaması 2.94'tür. Tablo 2'ye 
göre, araştırmaya katılan DeFacto hazır giyim markası kullanıcılarının negatif ağızdan ağıza pazarlamaya yönelik ifadelerinin orta düzeyin biraz altında olduğu görülmektedir.

Tablo 3: Marka Sadakati Ölçeği Betimsel İstatistiği

\begin{tabular}{|l||c||c|c|}
\hline Marka Sadakati Ölçeği & Kişi & Ortalama & $\begin{array}{c}\text { Standart } \\
\text { Sapma }\end{array}$ \\
\hline $\begin{array}{l}\text { DeFacto markasına bağlı olduğumu } \\
\text { düşünüyorum }\end{array}$ & 525 & 3.13 & 1.36 \\
\hline $\begin{array}{l}\text { DeFacto markasını kullanmaktan } \\
\text { memnunum }\end{array}$ & 525 & 3.07 & 1.02 \\
\hline \hline DeFacto markasına güvenirim & 525 & 3.29 & 1.17 \\
\hline $\begin{array}{l}\text { Her zaman DeFacto markasını satın } \\
\text { alırım }\end{array}$ & 525 & 3.25 & 1.33 \\
\hline $\begin{array}{l}\text { DeFacto markasına aynı kalitedeki diğer } \\
\text { markalardan daha fazla fiyat öderim }\end{array}$ & 525 & 2.71 & 1.32 \\
\hline \hline $\begin{array}{l}\text { DeFacto markası mağazada yoksa farklı } \\
\text { markalı ürünleri satın almam }\end{array}$ & 525 & 2.83 & 1.32 \\
\hline \hline Marka Sadakati (Genel Ortalama) & $\mathbf{5 2 5}$ & $\mathbf{3 . 0 5}$ & $\mathbf{0 . 9 2}$ \\
\hline \hline
\end{tabular}

DeFacto markası kullanıcılarına yönelik yapılan anket uygulaması neticesinde, bu markaya olan marka sadakati genel ortalama düzeyinin 3.05 olduğu görülmektedir. Tablo 3'deki değerlendirmelere göre, DeFacto markası kullanıcılarının marka sadakatinin orta değerin biraz üzerinde olduğu anlaşılmaktadır.

\section{Tablo 4: Markaya Yönelik Algılanan Kalite Ölçeği Betimsel İstatistiği}

\begin{tabular}{|l||c||c|c|}
\hline Algılanan Kalite Ölçeği & Kişi & Ortalama & $\begin{array}{c}\text { Standart } \\
\text { Sapma }\end{array}$ \\
\hline $\begin{array}{l}\text { DeFacto markasının pazarda en iyi } \\
\text { kaliteye sahip marka olduğunu } \\
\text { düşünüyorum }\end{array}$ & 525 & 2.93 & 1.14 \\
\hline $\begin{array}{l}\text { DeFacto markasının kalitesi çok } \\
\text { yüksektir }\end{array}$ & 525 & 2.97 & 1.07 \\
\hline $\begin{array}{l}\text { DeFacto markasının kalitesi } \\
\text { beklentilerimi karşı1lar }\end{array}$ & 525 & 3.03 & 1.13 \\
\hline $\begin{array}{l}\text { Yüksek kaliteli bir ürün almak istersem } \\
\text { DeFacto markasına her zaman güvenirim }\end{array}$ & 525 & 2.97 & 1.27 \\
\hline $\begin{array}{l}\text { DeFacto markasının kalitesinin gelecekte } \\
\text { de devam edeceğine inanırım }\end{array}$ & 525 & 3.11 & 1.08 \\
\hline $\begin{array}{l}\text { DeFacto markasının fonksiyonel } \\
\text { özellikleri çok yüksektir }\end{array}$ & 525 & 2.90 & 1.19 \\
\hline \hline Algılanan Kalite (Genel Ortalama) & $\mathbf{5 2 5}$ & $\mathbf{2 . 9 8}$ & $\mathbf{0 . 8 9}$ \\
\hline \hline
\end{tabular}


Araştırmada yer alan DeFacto hazır giyim markası kullanıcılarının bu markaya ilişkin ifadelerinin yer aldığı algılanan kalite ölçeğinin genel ortalama değeri 2.98'dir. Araştırmaya katılan DeFacto kullanıcılarının algılanan kalite ifadelerine yönelik değerlendirmeleri orta düzeye yakın bir seviyede olduğu görülmektedir.

\subsubsection{Araştırma Hipotezlerinin Test Edilmesi}

Araştırmada kullanılan verilerin normal dağılım gösterip göstermediklerini belirlemek amaciyla Kolmogorov-Smirnov testi yapılmış, Kurtosis ve Skewness değerlerinin $-1,5$ ve $+1,5$ değerleri arasında yer aldığı tespit edilmiştir. Tabachnick, Fidell ve Ullman (2007), Kurtosis ve Skewness değerleri -1,5 ve +1,5 aralığında yer aldığında normal dağılıma göre analizler yapılabileceğini ifade etmektedirler.

Araştırmanın amacına yönelik geliştirilen hipotezlerin analizi 0.95 güven aralığında değerlendirilmiştir. Hipotezlerin desteklenip desteklenmediğini belirlemek amacıyla korelâsyon ve çoklu regresyon analizi kullanılmıştır. Analiz sonuçlarına aşağıda tablolar halinde yer verilmektedir.

Hipotez 1: Tüketicilerin marka sadakati ile pozitif ă̆ızdan ă̆ıza pazarlama faaliyetleri arasında pozitif yönlü bir ilişki vardır.

DeFacto hazır giyim markasını kullanan tüketicilerin, marka sadakati ile pozitif ağızdan ağıza pazarlama faaliyetleri arasındaki ilişkiyi belirlemek amacıyla pearson korelâsyon analizi gerçekleştirilmiştir.

Tablo 5: Marka Sadakati ve Pozitif Ağızdan Ağıza Pazarlama İlişkisine Yönelik Korelâsyon Analizi Tablosu

\begin{tabular}{|c|c|c|}
\hline \multicolumn{2}{|c|}{ Korelâsyon Analizi } & $\begin{array}{c}\text { Pozitif A } \breve{g} ı z d a n \text { Ăgıza } \\
\text { Pazarlama }\end{array}$ \\
\hline \multirow{3}{*}{ Marka Sadakati } & Pearson Correlation & $.783^{* * *}$ \\
\hline & Sig. (2-tailed) & 000 \\
\hline & $\mathrm{N}$ & 525 \\
\hline
\end{tabular}

$* p<0,05 * * p<0,01$

Araştırmaya katılan DeFacto hazır giyim markası kullanıcılarının, marka sadakati ile pozitif ağızdan ağıza pazarlama faaliyetleri arasındaki ilişkiyi inceleyen korelâsyon analizi neticesinde, istatistiksel olarak anlamlı sonuçlar elde edilmiştir. DeFacto hazır giyim markası kullanıcılarının marka sadakati arttıkça pozitif ağızdan ağıza pazarlama faaliyetlerinde de, pozitif yönde 0.783 oranında artış olduğu tespit edilmiştir. Korelâsyon analizi neticesinde Hipotez 1'in desteklendiği görülmektedir.

Hipotez 2: Tüketicilerin marka sadakati ile negatif ă̆ıdan ă̆ıza pazarlama faaliyetleri arasında negatif yönlü bir ilişki vardır. 
DeFacto markasını kullanan tüketicilerin, marka sadakati ile negatif ağızdan ağıza pazarlama faaliyetleri arasındaki ilişkiyi belirlemek amacıyla pearson korelâsyon analizi gerçekleştirilmiştir.

Tablo 6: Marka Sadakati ve Negatif Ăğıdan Ăğıa Pazarlama İlişkisine Yönelik Korelâsyon Analizi Tablosu

\begin{tabular}{|c|c|c|}
\hline \multicolumn{2}{|c|}{ Korelâsyon Analizi } & 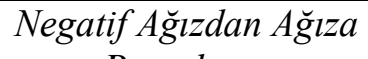 \\
\hline \multirow{3}{*}{ Marka Sadakati } & Pearson Correlation & $-.583^{* * *}$ \\
\hline & Sig. (2-tailed) & 000 \\
\hline & $\mathrm{N}$ & 525 \\
\hline
\end{tabular}

$* p<0,05 * * p<0,01$

Tablo 6'da yer alan korelâsyon analizi sonuçlarına göre, DeFacto kullanıcılarının marka sadakati ile negatif ağızdan ağıza pazarlama faaliyetleri arasında negatif yönlü ve anlamlı bir ilişki olduğu tespit edilmiştir. Katılımcıların marka sadakati arttıkça, DeFacto markasına yönelik negatif ağızdan ağıza pazarlama faaliyetlerinde 0.583 oranında azalma olduğu görülmektedir. Korelâsyon analizi sonuçlarına göre Hipotez 2'nin desteklendiği görülmektedir.

Hipotez 3: Tüketicilerin markaya yönelik kalite algılarl ile pozitif ağızdan ă̆ıza pazarlama faaliyetleri arasında pozitif yönlü bir ilişki vardır.

DeFacto hazır giyim markasını kullanan tüketicilerin, markaya yönelik kalite algısı ile pozitif ağızdan ağıza pazarlama faaliyetleri arasındaki ilişkiyi belirlemek amacıyla pearson korelâsyon analizi gerçekleştirilmiştir.

Tablo 7: Algılanan Kalite ve Pozitif Ağızdan Ağıza Pazarlama İlişkisine Yönelik Korelâsyon Analizi Tablosu

\begin{tabular}{|c|c|c|}
\hline \multicolumn{2}{|c|}{ Korelâsyon Analizi } & 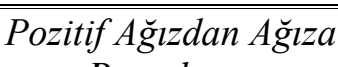 \\
\hline \multirow{3}{*}{ Algılanan Kalite } & Pearson Correlation & $.791^{* * *}$ \\
\hline & Sig. (2-tailed) & 000 \\
\hline & $\mathrm{N}$ & 525 \\
\hline
\end{tabular}

$* p<0,05 * * p<0,01$

Araştırmaya katılan DeFacto hazır giyim markası kullanıcılarının, markaya yönelik kalite algısı ile pozitif ağızdan ağıza pazarlama faaliyetleri arasındaki ilişkiyi inceleyen pearson korelâsyon analizi neticesinde, istatistiksel olarak anlamlı sonuçlar elde edilmiştir. DeFacto hazır giyim markası kullanıcılarının kalite algısı arttıkça pozitif ağızdan ağıza pazarlama faaliyetlerinde de pozitif yönde 0.791 oranında artış olduğu tespit edilmiştir. Korelâsyon analizi neticesinde Hipotez 3'ün desteklendiği görülmektedir. 
Hipotez 4: Tüketicilerin markaya yönelik kalite algıları ile negatif ă̆ızdan ă̆ıza pazarlama faaliyetleri arasında negatif yönlü bir ilişki vardır.

DeFacto markasını kullanan tüketicilerin, markaya yönelik kalite algısı ile negatif ağızdan ağıza pazarlama faaliyetleri arasındaki ilişkiyi belirlemek amacıyla pearson korelâsyon analizi gerçekleştirilmiştir.

Tablo 8: Algılanan Kalite ve Negatif Ăgızdan Ă̆ıza Pazarlama İlişkisine Yönelik Korelâsyon Analizi Tablosu

\begin{tabular}{|c|c|c|}
\hline \multicolumn{2}{|c|}{ Korelâsyon Analizi } & 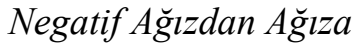 \\
\hline \multirow{3}{*}{ Algilanan Kalite } & Pearson Correlation & $-.497^{* *}$ \\
\hline & Sig. (2-tailed) & 000 \\
\hline & $\mathrm{N}$ & 525 \\
\hline
\end{tabular}

Tablo 8'de yer alan pearson korelâsyon analizi sonuçlarına göre, DeFacto kullanıcılarının markaya yönelik kalite algısı ile negatif ağızdan ağıza pazarlama faaliyetleri arasında negatif yönlü ve anlamlı bir ilişki olduğu tespit edilmiştir. Katılımcıların markaya yönelik kalite algısı arttıkça, DeFacto markasına yönelik negatif ağızdan ağıza pazarlama faaliyetlerinde 0.497 oranında azalma olduğu görülmektedir. Korelâsyon analizi sonuçlarına göre Hipotez 4'ün desteklendiği görülmektedir.

Hipotez 5: Tüketicilerin marka sadakati ve markaya yönelik kalite algıları, pozitif ă̆ızdan ăgıza pazarlama faaliyetlerini pozitif yönde etkilemektedir.

DeFacto hazır giyim markası kullanıcılarının marka sadakati ve markaya yönelik kalite algılarının, pozitif ağızdan ağıza pazarlama faaliyetlerine etkisini belirlemek amaciyla çoklu regresyon analizi gerçekleştirilmiştir.

Tablo 9: Hipotez 5'e Yönelik Çoklu Regresyon Analizi

\begin{tabular}{|c|c|c|c|c|c|c|}
\hline Bağımsız Değişken & $\mathbf{R}^{2}$ & $\mathbf{F}$ & $\boldsymbol{\beta}$ & $\mathbf{t}$ & $\mathbf{p}$ & $\begin{array}{l}\text { Durbin } \\
\text { Watson }\end{array}$ \\
\hline Marka Sadakati & \multirow{2}{*}{.683} & \multirow{2}{*}{$561.220^{* *}$} & .464 & 9.698 & $.000^{* * *}$ & \multirow{2}{*}{2.122} \\
\hline Algilanan Kalite & & & 2.527 & $\begin{array}{l}10.648 \\
\end{array}$ & $.000^{* * *}$ & \\
\hline
\end{tabular}

$* p<0,05 * * p<0,01$

DeFacto hazır giyim markası kullanıcılarının, marka sadakati ile markaya yönelik kalite algılarının, bu marka ile ilgili pozitif ağızdan ağıza pazarlama faaliyetlerine etkisini belirlemek amacıyla gerçekleştirilen çoklu regresyon analizi neticesinde, istatistiksel olarak anlamlı sonuçlar elde edilmiştir. DeFacto markası 
kullanıcılarının markaya yönelik pozitif ağızdan ağıza pazarlama faaliyetlerinin, marka sadakati ve markaya yönelik kalite algısı ile açıklanma oranı $\left(\mathrm{R}^{2}\right)$ 0.683'tür. DeFacto kullanıcılarının marka sadakati ve markaya yönelik kalite algılarındaki 1 birimlik artışın, pozitif ağızdan ağıza pazarlama faaliyetleri üzerinde 0.683 oranında artışa neden olduğu belirlenmiştir. Beta değerleri incelendiğinde, marka sadakatinin 0.464 oranında, markaya yönelik kalite algısının ise 0.527 oranında pozitif ağızdan ağıza pazarlama faaliyetlerini etkilediği görülmektedir. Regresyon modelinde, değişkenler arasında otokorelasyon olup olmadığı Durbin-Watson testi ile belirlenmektedir. Genellikle 1,5 - 2,5 aralığındaki Durbin-Watson testi değeri, otokorelasyon olmadığının göstergesidir (Öztürk, 2008, s. 267). Çoklu regresyon analizi Durbin-Watson değeri (2.122) incelendiğinde, bu aralık içerisinde yer aldığını söylemek mümkündür. Çoklu regresyon analizi sonuçlarına göre Hipotez 5 'in desteklendiği görülmektedir.

Hipotez 6: Tüketicilerin marka sadakati ve markaya yönelik kalite algıları, negatif ağızdan ă̆ıza pazarlama faaliyetlerini negatif yönde etkilemektedir.

Hipotez 6'yı test etmek amacıyla, DeFacto hazır giyim markası kullanıcılarının marka sadakati ve markaya yönelik kalite algılarının, negatif ağızdan ağıza pazarlama faaliyetlerine etkisini belirlemek amacıyla çoklu regresyon analizi gerçekleştirilmiştir.

Tablo 10: Hipotez 6'ya Yönelik Çoklu Regresyon Analizi

\begin{tabular}{|c|c|c|c|c|c|c|}
\hline Bağımsız Değişken & $\mathbf{R}^{2}$ & $\mathbf{F}$ & $\boldsymbol{\beta}$ & $\mathbf{t}$ & $\mathbf{p}$ & $\begin{array}{l}\text { Durbin } \\
\text { Watson }\end{array}$ \\
\hline Marka Sadakati & \multirow{2}{*}{.341} & \multirow{2}{*}{$135.079^{* *}$} & -.507 & -8.632 & $.000^{* *}$ & \multirow{2}{*}{2.286} \\
\hline Algilanan Kalite & & & -.064 & -1.052 & .293 & \\
\hline
\end{tabular}

$* p<0,05 * * p<0,01$

Araştırmaya katılan DeFacto markası kullanıcılarının, marka sadakati ile markaya yönelik kalite algılarının, bu marka ile ilgili negatif ağızdan ağıza pazarlama faaliyetlerine etkisini belirlemek amaciyla çoklu regresyon analizi gerçekleştirilmiş ve anlamlı sonuçlar elde edilmiştir. DeFacto markası kullanıcılarının markaya yönelik negatif ağızdan ağıza pazarlama faaliyetlerinin, marka sadakati ve markaya yönelik kalite algısı ile açıklanma oranı $\left(\mathrm{R}^{2}\right)$ 0.341 'dir. DeFacto kullanıcılarının marka sadakati ve markaya yönelik kalite algılarındaki 1 birimlik artışın, negatif ağızdan ağıza pazarlama faaliyetleri üzerinde 0.341 oranında azalışa neden olduğu tespit edilmiştir. Beta değerleri incelendiğinde, marka sadakatinin negatif ağızdan ağıza pazarlama faaliyetlerini 0.507 oranında azalttığı görülmektedir. Markaya yönelik kalite algısının p değeri 
(.293), 0.95 güven aralığında 0.05 hata payı ile değerlendirildiğinde, negatif ağızdan ağıza pazarlama üzerinde istatistiksel olarak anlamlı bir etkisinin olmadığı tespit edilmiştir. Durbin-Watson değeri (2.286) incelendiğinde, değişkenler arasında oto korelâsyon olmadığ 1 belirlenmiştir. Çoklu regresyon analizi sonuçlarına göre Hipotez 6'nın marka sadakati açısından desteklendiği ancak algılanan kalite için desteklenmediği görülmektedir.

\section{Değerlendirme ve Sonuç}

Tüketicilerin ağızdan ağıza pazarlama faaliyetlerinde marka sadakati ve markaya yönelik algılanan kalitenin etkisini araştıran bu çalışmada, istatistiksel olarak anlamlı sonuçlar elde edilmiştir. DeFacto mallarını kullanan tüketicilerin ağızdan ağıza pazarlama faaliyetlerine yönelik betimsel istatistik değerleri incelendiğinde, pozitif ağızdan ağıza pazarlama faaliyetlerinin negatif ağızdan ağıza pazarlama faaliyetlerine göre biraz daha yüksek düzeyde olduğu belirlenmiştir. DeFacto mallarını kullanan tüketicilerin marka sadakatine ilişkin betimsel istatistik değerleri orta düzeydedir. Markaya yönelik kalite algıları ise orta düzey seviyesindedir.

Araştırmaya katılan tüketicilerin marka sadakati ile pozitif ağızdan ağıza pazarlama faaliyetleri arasındaki ilişkinin incelendiği korelâsyon analizine göre yüksek düzeyde ilişki olduğu belirlenmiştir. Marka sadakati yüksek olan DeFacto kullanıcılarının pozitif ağızdan ağıza pazarlama faaliyetlerinin de yüksek olduğu gözlenmektedir. Marka sadakati ile negatif ağızdan ağıza pazarlama faaliyetlerindeki ilişki incelendiğinde ters yönlü bir ilişkinin olduğu belirlenmiştir. Marka sadakati yükseldikçe negatif ağızdan ağıza pazarlama faaliyetlerinde düşüş olduğu tespit edilmiştir.

Araştırmaya katılan DeFacto kullanıcılarının markaya yönelik kalite algısı arttıkça pozitif ağızdan ağıza pazarlama faaliyetlerinde de artış olduğu görülmektedir. Markaya yönelik algılanan kalite ile pozitif ağızdan ağıza pazarlama faaliyetleri arasında olumlu yönde ilişki olduğu tespit edilmiştir. Araştırmaya katılan DeFacto kullanıcılarının markaya yönelik kalite algıları arttıkça negatif ağızdan ağıza pazarlama faaliyetlerinde azalma olduğu görülmektedir. Gülmez ve Özaltın Türker (2015) tarafından yapılan araştırmada da pozitif ağızdan ağıza pazarlama ile markaya yönelik algılanan kalite arasında pozitif yönlü ve anlamlı düzeyde, negatif ağızdan ağıza pazarlama ile de ters yönlü ilişki içerisinde olduğu tespit edilmiştir. Markovic vd. (2018) tarafından yapılan araştırmada da marka sadakati ve algılanan kalite ile ağızdan ağıza pazarlama arasında pozitif yönlü bir ilişki olduğu belirlenmiştir.

Marka sadakati ve markaya yönelik algılanan kalitenin, pozitif ağızdan ağıza pazarlama faaliyetleri üzerindeki etkisini belirlemek amacıyla yapılan çoklu regresyon analizi neticesinde istatistiksel olarak anlamlı sonuçlar elde edilmiştir. DeFacto markasına yönelik marka sadakati ve algılanan kalitenin pozitif ağızdan 
ağıza pazarlama faaliyetlerini olumlu yönde etkilediği, negatif ağızdan ağıza pazarlama faaliyetlerini de azaltıcı etkisi olduğu belirlenmiştir. Literatürde yapılan benzer araştırmalarda da marka sadakati ve markaya yönelik algılanan kalitenin ağızdan ağıza pazarlamayı olumlu yönde etkilediği tespit edilmiştir (Murtiasih ve Siringoringo, 2013; Severi vd., 2014; Virvilaite vd., 2015; Yazgan vd., 2014; Y1ld1z, 2015)

Sonuç olarak, DeFacto kullanan tüketicilerin pozitif ve negatif ağızdan ağıza pazarlama faaliyetlerinde marka sadakati ve markaya yönelik algılanan kalitenin etkisinin olduğu tespit edilmiştir. Teknolojinin gelişmesi ile birlikte ağızdan ağıza pazarlama faaliyetlerinde de artış meydana gelmiştir. İşletmelerin rakiplerine nazaran rekabet avantajı elde etmelerinde ağızdan ağıza pazarlama faaliyetlerinin önemi giderek artmaktadır. İşletmelerin pazarlama departmanları içerisinde oluşturacakları bir birim ile ağızdan ağıza pazarlama faaliyetlerini kontrol altına almaları gerekmektedir. Tüketicilerin pozitif ağızdan ağıza pazarlama faaliyetlerini arttırmaya yönelik stratejilerin belirlenmesi gerekmektedir. Araştırma sonucunda, ağızdan ağıza pazarlama faaliyetlerinde tüketicilerin marka sadakatinin ve kalite algısının önemli düzeyde olduğu görülmektedir. İşletmelerin marka sadakati oluşturacak faaliyetler içerisinde olmaları ve tüketicilerin markaya yönelik kalite algılarının yükseltilmesi gerekmektedir. Özellikle sosyal medya ortamlarında tüketicilerin markaya yönelik negatif ağızdan ağıza pazarlama faaliyetleri yakından takip edilmeli, tüketici şikâyetleri dikkate alınarak giderilmeli ve marka üzerindeki olumsuz tutumların ortadan kaldırılmasına çalışılmalıdır. Araştırma neticesinde sonraki çalışmalara öneri olarak, ağızdan ağıza pazarlama faaliyetleri üzerinde etkisi olan diğer unsurların neler olabileceği konusunda yapılan araştırmaların, hem iş dünyası açısından hem de akademik çalışmalar açısından katkı sunacağı düşünülmektedir. Ayrıca farklı sektörlerde yapılacak benzer araştırmaların karşılaştırma yapabilmek adına iş dünyasına ve bilim camiasına katkısı olacağı açıktır.

\section{Kaynakça}

Aaker, D. (1991). Managing brand equity. New York: Free Press.

Akin, M. (2017). The effects of young consumers' love for smart mobile phone brands on brand loyalty, International Review of Management and Business Research, 6(1), 362-370.

Alexandris, K., Tsaousi, E. ve James, J. (2007). Predicting sponsorship outcomes from attitudinal constructs: The case of a professional basketball event. Sport Marketing Quarterly, 16(3), 130-139.

Anderson, E. W. ve Salisbury, L. C. (2003). The formation of market-level expectations and its covariates. Journal of Consumer Research, 30(1), 115-124. 
Aşkın, N. ve İpek, İ. (2016). Marka aşkının marka deneyimi ile marka sadakati arasındaki ilişkiye aracılık etkisi. Ege Akademik Bakış Dergisi, 16(1), 7994.

Batra, R., Ahuvia, A. ve Bagozzi, R. P. (2012). Brand love. Journal of Marketing, 76(2), 1-16.

Bayındır, N. S. (2019). Hizmet sektöründe algılanan adalet, telafi sonrası tüketici tatmini ve ă̆ızdan ă̆ıza pazarlama ilişkisi: Bankacılık sektöründe bir uygulama, Yayımlanmamış Yüksek Lisans Tezi, İstanbul: İstanbul Arel Üniversitesi.

Berger, J. ve Schwartz, E. M. (2011). What drives immediate and ongoing word of mouth?. Journal of Marketing Research, 48(5), 869-880.

Bergkvist, L. ve Bech-Larsen, T. (2010). Two studies of consequences and actionable antecedents of brand love. Journal of Brand Management, 17(7), 504-518.

Carl, W. J. (2006). What's all the buzz about? Everyday communication and the relational basis of word-of-mouth and buzz marketing practices. Management Communication Quarterly, 19(4), 601-634.

Carroll, B. A. ve Ahuvia, A. C. (2006). Some antecedents and outcomes of brand love. Marketing Letters, 17(2), 79-89.

Chae, I., Stephen, A. T., Bart, Y. ve Yao, D. (2017). Spillover effects in seeded word-of-mouth marketing campaigns. Marketing Science, 36(1), 89-104.

Chung, C. M. ve Darke, P. R. (2006). The consumer as advocate: Self-relevance, culture and word-of-mouth. Marketing Letters, 17(4), 269-279.

Çifci, S. (2006). Marka ve marka sadakati üniversite ögrencilerinin kot pantolon marka tercihleri ve marka sadakatleri ile ilgili bir araştırma. Yayımlanmamış Yüksek Lisans Tezi, Bolu: Abant İzzet Baysal Üniversitesi.

Dafonte-Gómez, A. (2013). The key elements of viral advertising. from motivation to emotion in the most shared videos. Media Education Research Journal, 22 (43), 199-206.

Dağc1 Büyük, H. ve Erciş, A . (2016). İndirim marketlerinde müşteri değerinin müşteri tatmini, müşteri sadakati ve ağızdan ağıza iletişime etkisi. Atatürk Üniversitesi İktisadi ve İdari Bilimler Dergisi, 30 (3) , 527-544. 
Dellarocas, C. (2003). The digitization of word of mouth: Promise and challenges of online feedback mechanisms. Management Science, 49(10), 1407-1424.

Dick, A. S. ve Basu, K. (1994). Customer loyalty: toward an integrated conceptual framework. Journal of The Academy of Marketing Science, 22(2), 99-113.

Drennan, J., Bianchi, C., Cacho-Elizondo, S., Louriero, S., Guibert, N. ve Proud, W. (2015). Examining the role of wine brand love on brand loyalty: A multi-country comparison. International Journal of Hospitality Management, 49, 47-55.

Elden, M. (2009) Reklam ve reklamcılık, İstanbul: Say Yayınları.

Godes, D. ve Mayzlin, D. (2004). Using online conversations to study word-ofmouth communication. Marketing Science, 23(4), 545-560.

Goyette, I., Ricard, L., Bergeron, J. ve Marticotte, F. (2010). e-WOM Scale: word-of-mouth measurement scale for e-services context. Canadian Journal of Administrative Sciences 27(1), 5-23.

Gülmez, M. ve Özaltın Türker, G. (2015). Ağızdan ağıza iletişim ile tüketici odaklı marka değeri arasındaki ilişkinin incelenmesi: Tur operatörleri ve seyahat acenteleri müşterileri üzerine bir uygulama. Seyahat ve Otel İşletmeciliği Dergisi, 12(1), 64-81.

Gürbüz, A. ve Doğan, M. (2013). Tüketicilerin markaya duyduğu güven ve marka bağlılığı ilişkisi. Uluslararası Yönetim İktisat ve İşletme Dergisi, 9(19), 239-258.

Güven, E. (2014). Sosyal medyadaki ă̆ızdan ă̆ıza pazarlama faaliyetlerinin satın alma kararları üzerine etkileri, Yayımlanmamış Doktora Tezi, Manisa: Celal Bayar Üniversitesi.

Hahn, M., Park, S., Krishnamurthi, L. ve Zoltners, A. A. (1994). Analysis of new product diffusion using a four-segment trial-repeat model. Marketing Science, 13(3), 224-247.

Harrison-Walker, L. J. (2001). The measurement of word-of-mouth communication and an investigation of service quality and customer commitment as potential antecedents. Journal of Service Research, 4(1), $60-75$.

Hennig-Thurau, T., Gwinner, K. P., Walsh, G. ve Gremler, D. D. (2004). Electronic word-of-mouth via consumer-opinion platforms: what 
motivates consumers to articulate themselves on the internet? Journal of Interactive Marketing, 18(1), 38-52.

Heskett, J. L., Jones, T. O., Loveman, G. W., Sasser, W. E. ve Schlesinger, L. A. (1994). Putting the service-profit chain to work. Harvard Business Review, 72(2), 164-174.

Huang, C. C. (2017). The impacts of brand experiences on brand loyalty: mediators of brand love and trust. Management Decision. 55 (5), 915-934.

Hung, C. H. (2008). The effect of brand image on public relations perceptions and customer loyalty. International Journal of Management, 25(2), 237-246.

Hur, W. M., Kim, M. ve Kim, H. (2014). The role of brand trust in male customers' relationship to luxury brands. Psychological Reports, 114(2), 609-624.

Iacobucci, D. ve Hopkins, N. (1992). Modelling dyadic interactions and networks in marketing. Journal of Marketing Research, 29(1), 5-17.

Işı1k, O. (2016). Algılanan kalitenin hastane marka değerine etkisi. Hacettepe Sağlık İdaresi Dergisi, 19(1), 57-72.

Kadaifçiler, A. (2019). Marka sadakatinin tüketicinin satın alma karar süreci ile ilişkisi: Konya ili hazır giyim pazarı örneği. Yayımlanmamış Yüksek Lisans Tezi, Konya: KTO Karatay Üniversitesi.

Kahn, B. ve Wind, J. (2005). What's the buzz about buzz marketing? USA: Knowledge@Wharton.

Kalaycı, Ş. (2008). Güvenilirlik analizi, İçinde Ş.Kalaycı (Ed). SPSS Uygulamalı Çok Değişkenli İstatistik Teknikleri (3.Baskı). Ankara: Asil Yayın Dağıtım.

Kalyoncuoğlu, S. (2017). Markaya Duyulan Güven ile Marka Sadakati İlişkisinde Marka Aşkının Aracılık Rolü: Starbucks Markası Üzerine Bir Araştırma, Journal of Tourism and Gastronomy Studies, 5(4), 383-402.

Khan, I., ve Fatma, M. (2019). Connecting the dots between CSR and brand loyalty: the mediating role of brand experience and brand trust. International Journal of Business Excellence, 17(4), 439-455.

Langner, T., Bruns, D., Fischer, A. ve Rossiter, J. R. (2016). Falling in love with brands: a dynamic analysis of the trajectories of brand love. Marketing Letters, 27(1), 15-26. 
Litvin, S. W., Goldsmith, R. E. ve Pan, B. (2008). Electronic word-of-mouth in hospitality and tourism management. Tourism management, 29(3), 458468.

Marangoz, M. (2007). Ağızdan ağıza iletişimin müşterilerin satın alma davranışlarına etkileri: Cep telefonu pazarına yönelik bir araştırma. Çukurova Üniversitesi Sosyal Bilimler Enstitüsü Dergisi, 16(2), 395-412.

Markovic, S., Iglesias, O., Singh, J. J. ve Sierra, V. (2018). How does the perceived ethicality of corporate services brands influence loyalty and positive word-of-mouth? Analyzing the roles of empathy, affective commitment, and perceived quality. Journal of Business Ethics, 148(4), 721-740.

Merlo, O., Eisingerich, A. B. ve Auh, S. (2014). Why customer participation matters. MIT Sloan Management Review, 55(2), 81-88.

Mohr, I. (2007). Buzz marketing for movies. Business Horizons, 50(5), 395-403.

Mosavi, S. A. ve Kenarehfard, M. (2013). The impact of value creation practices on brand trust and loyalty in a Samsung Galaxy online brand community in Iran. International Journal of Mobile Marketing, 8(2), 75-84.

Mostert, P. G., Petzer, D. J. ve Weideman, A. (2016). The interrelationships between customer satisfaction, brand loyalty and relationship intentions of Generation Y consumers towards smart phone brands. South African Journal of Business Management, 47(3), 25-34.

Murray, K. B. (1991). A test of services marketing theory: Consumer information acquisition activities. Journal of Marketing, 55(1), 10-25.

Murtiasih, S. ve Siringoringo, H. (2013). How word of mouth influence brand equity for automotive products in Indonesia. Procedia-Social and Behavioral Sciences, 81, 40-44.

Netemeyer, R. G., Krishnan, B., Pullig, C., Wang, G., Yagci, M., Dean, D., Ricks, J. ve Wirth, F. (2004). Developing and validating measures of facets of customer-based brand equity. Journal of Business Research, 57(2), 209224.

Oliver, R. L. (1999). Whence consumer loyalty? Journal of marketing, 63(4), 3344.

Onaran, B., Bulut, Z. A. ve Özmen, A. (2013). Müşteri değerinin, müşteri tatmini, marka sadakati ve müşteri ilişkileri yönetimi performansı üzerindeki 
etkilerinin incelenmesine yönelik bir araştırma. Business \& Economics Research Journal, 4(2). 37-53.

Öztürk, E. (2008). Çoklu doğrusal regresyon modeli, İçinde Ş.Kalaycı (Ed). SPSS Uygulamalı Çok Değişkenli İstatistik Teknikleri (3.Bask1). Ankara: Asil Yayın Dağıtım.

Pappu, R. ve Quester, P. (2016), How does brand innovativeness affect brand loyalty?, European Journal of Marketing, 50 (1/2), 2-28.

Pappu, R., Quester, P. G. ve Cooksey, R. W. (2005). Consumer-based brand equity: improving the measurement-empirical evidence. Journal of Product \& Brand Management, 14(3), 143-154.

Pappu, R., Quester, P. G. ve Cooksey, R. W. (2007). Country image and consumer-based brand equity: relationships and implications for international marketing. Journal of International Business Studies, 38(5), 726-745.

Reichheld, F. F. (2003). The one number you need to grow. Harvard Business Review, 81(12), 46-55.

Richins, M. L. (1983). Negative word-of-mouth by dissatisfied consumers: A pilot study. Journal of Marketing, 47(1), 68-78.

Şahin, E., ve Gültekin, C. (2017). Markaya duyulan güven ve etnosentrik eğilimlerin marka sadakatine etkisi: bir marka örneği. Süleyman Demirel Üniversitesi İktisadi ve İdari Bilimler Fakültesi Dergisi, 22(4), 993-1012.

Sekaran, U. (1992). Research methods of business. Canada: Jonh Wiley \& Sons.

Severi, E., Ling, K. C. ve Nasermoadeli, A. (2014). The impacts of electronic word of mouth on brand equity in the context of social media. International Journal of Business and Management, 9(8), 84-96.

Silverman, G. (2007). A Ăızdan ă̆ıza pazarlama: dünyanın en güçlü pazarlama yönteminin 28 sırrl (Çev. Ender Orfanl1). İstanbul: MediaCat Kitapları.

Sim, Ş. ve Toprak, M. (2012). Sinemayı hayata yaklaştırmak: Sahte belgesel (Mockumentary) Fine Arts, 7 (1), 1-10.

Tabachnick, B. G., Fidell, L. S. ve Ullman, J. B. (2007). Using multivariate statistics (Vol. 5). Boston: Pearson. 
Tan, M. F. (2019). Deneyimsel pazarlamanın marka tercihi, marka sadakati ve marka özgünlügüne etkisi: Giyim ürünleri üzerine bir araştırma. Yayımlanmamış Yüksek Lisans Tezi, Gaziantep: Gaziantep Üniversitesi.

Taşkın, Ç., Öztürk, O., Sürmeli, E. ve Tuncay, S. (2016). Online hizmet kalitesinin öncüllerinin yapısal eşitlik modelleme ile belirlenmesi. Süleyman Demirel Üniversitesi İktisadi ve İdari Bilimler Fakültesi Dergisi, 21(3). 799-817.

Thomas Jr, G. M. (2004). Building the buzz in the hive mind. Journal of Consumer Behaviour: An International Research Review, 4(1), 64-72.

Thorson, K. S. ve Rodgers, S. (2006). Relationships between blogs as eWOM and interactivity, perceived interactivity and parasocial interaction. Journal of Interactive Advertising, 6(2), 5-44.

Tosun, N. B. ve Turfanda, S. (2018). Sanal marka topluluklarının marka sadakati üzerindeki rolü. Yıldız Sosyal Bilimler Enstitüsü Dergisi, 2(2), 95-117.

Trusov, M., Bucklin, R. E. ve Pauwels, K. (2009). Effects of word-of-mouth versus traditional marketing: findings from an internet social networking site. Journal of Marketing, 73(5), 90-102.

Turner, R. E. ve Wrenn, B. (1993). Marketing management, analysis, planning, implementation and control, Canadian Seventh Edition, In: Philip Kotler, Ronald E. Turner. Instructor's Manual. Scarborough, Canada: PrenticeHall.

Ünal, S. ve Aydın, H. (2013). An investigation on the evaluation of the factors affecting brand love. Procedia-Social and Behavioral Sciences, 92, 76-85.

Uztuğ, F. (2005). Markan kadar konuş: Marka iletişimi stratejileri. İstanbul: MediaCat Yayınları.

Venkateswaran, P. S. ve Ambrin, M. (2019). A study on service quality, customer satisfaction and brand loyalty towards non-vegetarian hotels. International Journal of Research in Arts and Science, 5(4), 219-227.

Virvilaite, R., Tumasonyte, D. ve Sliburyte, L. (2015). The influence of word of mouth communication on brand equity: Receiver perspectives. ProcediaSocial and Behavioral Sciences, 213, 641-646.

Yang, K. F., Yang, H. W., Chang, W. Y. ve Chien, H. K. (2017). The effect of service quality among customer satisfaction, brand loyalty and brand image. In 2017 IEEE International Conference on Industrial Engineering and Engineering Management (pp. 2286-2290). 
Yazgan, H., Çatı, K. ve Kethüda, Ö. (2014). Tüketici temelli marka değerinin ağızdan ağza pazarlamaya etkisi. Cumhuriyet Üniversitesi İktisadi ve İdari Bilimler Dergisi, 15(1), 237-252.

Yıldız, E. (2014). Tüketici temelli marka dĕ̆eri ile ă̆ızdan ă̆ıza pazarlama arasındaki ilişkide marka tercihinin aracılık rolü, Yayımlanmamış Doktora Tezi, İstanbul: Haliç Üniversitesi.

Yıldız, E. (2015). Ağızdan ağıza iletişimin tüketici temelli marka değeri boyutlarına etkileri: marka imajının aracılık rolü. Business \& Economics Research Journal, 6(3), 163-181.

Yıldız, E. ve Koçan, M. (2019). Tüketici etnosentrizmi, algılanan kalite ve marka sadakatinin marka kişiliği üzerindeki etkisi: krem çikolata tüketicileri üzerine bir uygulama. Bingöl Üniversitesi Sosyal Bilimler Enstitüsü Dergisi, 9(17), 309-326.

Yıldız, E., ve Koç, M. E. (2017) Marka mirası ve marka güveninin satın alma niyeti, müşteri tatmini ve marka sadakati üzerindeki etkileri. Dumlupınar Üniversitesi Sosyal Bilimler Dergisi, Pazarlama Kongresi Özel Sayıs1, 86104.

Yıldız, S. ve Avcı, İ. (2019). Tüketici temelli marka değerinin taklit markalı ürün algısı üzerindeki etkisi. Bingöl Üniversitesi Sosyal Bilimler Enstitüsü Dergisi, 9(17), 189-214.

Yoo, B. ve Donthu, N. (2001). Developing and validating multidimensional consumer-based brand equity scale. Journal of Business Research, 52(1), $1-14$.

Zeithaml, V. A. (1988). Consumer perceptions of price, quality, and value: a means-end model and synthesis of evidence. Journal of Marketing, 52(3), 2-22. 


\section{A Research on The Impact of Brand Loyalty and Perceived Quality Towards Brand in Consumers' Mouth-To-Mouth Marketing Activities}

\section{Extended Abstract}

\section{Introduction}

Consumers consider to the experiences of those around them when purchasing goods and services. The comments made on the internet where the experiences of the goods and services they want to buy are shared can also be effective in the purchasing preferences of the consumers. Sharing of consumers' experiences about the goods they use or the services they purchase with other people is considered as word-of-mouth marketing. (Chae etc., 2016, p. 92). It is seen that word of mouth marketing shapes consumers' expectations for goods and services and affects their attitudes. (Anderson, 2003, p.115). In the research by Turner and Wrenn (1993, p.19). It has been determined that customers explain their satisfaction with the goods or services to an average of 3 people, and the situations they are dissatisfied with to an average of 11 people.

Brand loyalty refers to the commitment of consumers to the goods and services they buy. (Pappu, Quester \& Cooksey, 2007, p.728). Tosun \& Turfanda (2018, p.99) is considered as a transition to other branded goods and services when the price and ownership characteristics of goods and services used by consumers change.According to Dick \& Basu (1994, p. 100), brand loyalty is defined as the consumers' positive attitude towards a brand and the power to maintain this positive situation. Uztuğ $(2005$, p. 34) refers to the power of creating loyal customers while defining a strong brand.

Perceived quality towards the brand expresses the quality that consumers expect from the brand regarding goods and services. When there is a difference between the quality that consumers expect from the brand and the actual quality of the product, the perceived quality level of the brand decreases. The concept of quality is evaluated in two ways, objective and subjective. While the objective quality perception reveals the measurable and verifiable quality understanding, the subjective quality understanding reveals the perception of quality that shows differences in perception from consumer to consumer and which cannot be measured numerically (Zeithaml, 1988, p. 41).

Pappu, Quester, and Cooksey (2005, p.145) emphasized that the perceived quality of the brand is effective in distinguishing goods and services from other brands and the personal evaluations of consumers, the goods and services of that brand display a sense of superiority and excellence compared to other brands.

\section{Method}

The aim of this study is to measure the effects of brand loyalty and quality perception on the brand in positive and negative word of mouth marketing activities of consumers. In addition, the relationship between positive and negative word-of-mouth marketing activities and brand loyalty and quality perception towards the brand was also included. In order to achieve the purpose of the research, a survey was conducted for customers using the province of Muğla and the DeFacto ready-to-wear brand. The data obtained as a result of the questionnaire application were tried to be analyzed by descriptive statistical analysis, correlation analysis and regression analysis. The 
research covers the consumers who use the DeFacto ready-to-wear brand in the province of Muğla and its surroundings. In the province of Muğla and its surroundings, a survey was conducted with customers who have previously purchased and used DeFacto ready-to-wear brand products.

\section{Results and Discussion}

In this study, which investigated the effect of brand loyalty and perceived quality towards the brand in the word-of-mouth marketing activities of consumers, statistically significant results were obtained. When the descriptive statistics regarding word-of-mouth marketing activities of consumers using DeFacto products are analyzed, it was determined that positive word-of-mouth marketing activities were slightly higher than negative word-of-mouth marketing activities. Obtaining explanatory information about the brand loyalty of consumers who use DeFacto products is moderate. Quality perceptions towards the brand are at a medium level. According to the correlation analysis, which examines the relationship between the brand loyalty of the consumers participating in the research and positive word of mouth marketing activities, it was determined that there is a high level of relationship. It is seen that word of mouth marketing activities of DeFacto users with high brand loyalty are also positive. When the relationship between brand loyalty and negative word of mouth marketing activities is examined, it is determined that there is a reverse relationship. It has been determined that as brand loyalty increases, there is a decrease in negative word-of-mouth marketing activities.

As the quality perception of DeFacto users participating in the research increases, it is seen that there is an increase in positive word of mouth marketing activities. It has been determined that there is a positive relationship between perceived quality for the brand and positive word of mouth marketing activities. In order to determine the effect of brand loyalty and perceived quality towards the brand on positive word of mouth marketing activities, statistically significant results were obtained as a result of the multiple regression analysis. It has been determined that brand loyalty and perceived quality towards the DeFacto brand positively affect word-of-mouth marketing activities, and have a negative effect on negative word-of-mouth marketing activities.

\section{Conclusion}

It has been determined that the positive and negative word-of-mouth marketing activities of consumers using DeFacto have an effect on brand loyalty and perceived quality towards the brand. Word of mouth marketing activities are increasingly important for businesses to gain competitive advantage over their competitors. Businesses need to control word-of-mouth marketing activities with a unit that they will create within their marketing department. Strategies to increase positive word-of-mouth marketing activities of consumers should be determined.

As a result of the research, it is seen that the brand loyalty and quality perception of consumers in word of mouth marketing activities are important. Businesses should be involved in activities that will create brand loyalty and consumers' quality perceptions should be increased. Especially in social media environments, negative word-of-mouth marketing activities of consumers towards the brand should be closely monitored, should be eliminated by taking customer complaints into consideration, and negative attitudes on the brand should be tried to be eliminated. As a result of the research, it is thought that researches on what other factors may affect word of mouth marketing activities will contribute to future studies both for the business world and academic studies. In addition, it is clear that similar studies in different sectors will contribute to the business world and the scientific community in order to make comparisons. 